\title{
Ancient History and Contemporary Political Theory: the Case of Liberty
}

The central theme of this special issue is the ancient notions of liberty, as articulated in the Ancient Near East, Classical and Hellenist Greece, Republican and Imperial Rome, Sasanian Empire, and the Eastern Roman Empire and Byzantium. As in the contemporary world, in antiquity liberty meant different things to different people. ${ }^{1}$ Liberty as a status characterised by the absence of slavery, liberty as freedom from external as well as internal constraints to achieve one's own chosen ends, and liberty as freedom to realise one's own potential or capability, are just a few of the articulations of this ideal in the ancient historical contexts examined here. ${ }^{2}$

This special issue originates from two impulses: first, to broaden our understanding of the conceptual articulations of liberty in the ancient world, from beyond the Graeco-Roman world to other ancient societies to which this world was connected; and second, to investigate the potential offerings of these ancient societies to our contemporary intellectual world.

The colloquium held in June 2015 at University College London accordingly gathered historians of antiquity whose specialisms are geographically and temporally diverse, from the Middle Eastern societies of the second millennium BCE to the Byzantine Empire, together with political theorists and legal and political philosophers interested in conceptions of liberty. The general aim was to establish a dialogue that would shed light on rival understandings of liberty in antiquity, and on the role that these might play in current thinking about this concept. More specifically, the intent was to address and consolidate the position of the ancient world within wider scholarly debates on the notions of liberty and the connected issue of the power of the state, and to explore whether, alongside the well-known Republican conception of liberty, on whose revival in our contemporary politics much has been written, antiquity might provide us with further intellectual alternatives with which to read and analyse the world we currently inhabit. ${ }^{3}$ To address such questions, Kinch Hoekstra and Quentin Skinner were invited to comment on all the papers delivered at the colloquium, specifically with a view to considering their implications for normative contemporary conceptualisations of liberty. To reflect this commitment, this special issue ends with a revised version of their comments, delivered at the end of the colloquium

\footnotetext{
${ }^{1}$ Throughout this special issue the nouns 'liberty' and 'freedom' will be used interchangeably as their differences do not seem to pertain conceptually to the ancient texts here examined - see, however, an important exception in Stökl, below 000. On this issue see H.F. Pitkin, 'Are Freedom and Liberty Twins?', Political Theory 16.4 (1988): 523-52.

${ }^{2}$ For a recent, very clear, exposition of the possible articulations of liberty see D. Schimdtz and J. Brennan, The Brief History of Liberty (Malden MA - Oxford, 2010), 1-29.

${ }^{3}$ Much of this revival is associated with the works of Quentin Skinner and Philip Pettit, first and most of all exemplified in Q. Skinner, Liberty before Liberalism (Cambridge UK, 1998) and P. Pettit, Republicanism: a Theory of Freedom and Government (Oxford, 1997). See, more recently, for a comprehensive survey of republican political theory and its normative proposals C. Laborde and J. Maynor (eds.), Republicanism and Political Theory (Malden MA - Oxford, 2008).
} 
during the final roundtable. These have been slightly modified to take into account the published versions of the essays; the conversational tone of the discussion has been retained, in order to preserve the open nature of a debate that is predicated upon the firm belief in the fruitful continuous dialogue between historical enquiry and theoretical political analysis.

A central concern of this special issue is therefore to reaffirm the importance of the ancient world in the wider field of the history of political thought. Despite some notable exceptions, ${ }^{4}$ the general trend in the scholarship on ideas about freedom in antiquity has been dominated by either decontextualized linear narratives, arranged chronologically from a putative beginning to a putative end, or by authorby-author studies of rather limited breadth. ${ }^{5}$ As a result, works concerned with modern notions of freedom have either ignored the ancient articulations of this value, relegated them to a learned footnote, or, at best, used them selectively to grant ad hoc authority to the conception of this ideal being advocated. In the past twenty years or so, however, some philosophers and modern historians, most notably perhaps Philip Pettit and Quentin Skinner, have turned their attention to the ancient world, and particularly to the Roman Republic, to explore and in some senses revive what they consider a distinctive trait of its ideological tradition - the notion of freedom as absence of domination or dependence upon the arbitrary will of someone else.

In relation to these scholarly trends, this investigation makes three main interventions: first, it broadens the geographical scope of the ancient history of liberty, moving away from a strictly classical, Graeco-Roman focus to include the Ancient Middle East by investigating ancient Syria, Israel, Iran, and Byzantium. Second, it considerably widens the chronological scope of the traditional historical investigation. Rather than focusing exclusively on classical Athens or Rome and their great thinkers, which clusters attention chronologically around the fifth to fourth centuries BCE in Greece and the first century $\mathrm{BCE}$ to the first century $\mathrm{CE}$ in Rome, ${ }^{6}$ this special issue covers a chronological range from the second millennium BCE down to the Byzantine empire. Third, and perhaps more importantly, this volume does not attempt to compose an overarching linear history of the ancient notion of liberty, reflecting the underlying conviction, following the Rortyan view of the centrality of contingency in the conceptualisation and adoption of political values, ${ }^{7}$ that such a history cannot be written. What can be written, however, is a history of ancient notions of liberty as adopted at specific times and places. Building on the foundations laid by Quentin Skinner, the work here is constructed upon a series of well-

\footnotetext{
${ }^{4}$ One of the most remarkable exceptions is O. Patterson, Freedom, Volume 1: Freedom in the Making of Western Culture (London, 1991).

${ }^{5}$ A very recent approach to the writing of the history of ancient liberty focuses on those who fought in the name of this value, such as, for example, Spartacus and Boudica See M. Ferrar, The Fight for Freedom (London, 2016).

${ }^{6}$ Current scholarship on the intellectual world of ancient Greece is currently breaking loose from the tyranny of classical Athens see, for example, B Gray, Stasis and Stability. Exile, the Polis, and Political Thought c. 404146 BC (Oxford, 2015), whilst V. Arena, Libertas and the Practice of Politics in the late Roman Republic (Cambridge UK, 2012), attempts to move away from the centrality of Cicero. Very interesting studies are still carried out on the notion of liberty as elaborated by some of the greatest classical authors, who play a large role in the development of the later political thought: alongside the contributions by Melissa Lane on Plato and Jed Atkins on Cicero in this special issue, see most recently on Tacitus T. Strunk, History after Liberty: Tacitus on Tyrants, Sycophants, and Republicans (Ann Arbor, 2016).

${ }^{7}$ R. Rorty, Contingency, Irony, and Solidarity (Cambridge UK, 1989).
} 
defined historical contexts, within which the notion of political liberty, broadly understood as the relation between the commonwealth and the civic members of the community, was conceptualised, reelaborated, transmitted, or adopted in the struggle for power, or, more generally, in the administration of their mutual civic relations. The result is a study of the processes of contingent adaptation and/or constant reinterpretation to which the idea of liberty has been variously subjected in these different ancient societies.

Perhaps the most ambitious aim unifying the contributions to this special issue, then, is to investigate whether, alongside the Republican way of thinking about liberty highlighted by theorists advocating a contemporary revival of Republicanism, the ancient world can offer us other ways of conceptualizing this ideal. It thereby seeks to broaden and further enrich the existing dialogue between the study of ancient history and contemporary political theory, in the hope that expanding our knowledge of the ancient world as a reservoir of potential intellectual resources to help clarify our thinking about the political world. ${ }^{8}$ The guiding assumption of such an enterprise is that history, and more specifically here the history of the ancient world, when analysed through the heuristic lenses of analytical political philosophy may have something to offer us that goes beyond the clarification or even the comprehension of historical questions concerning the ancient societies under scrutiny: it may help us address the most pressing evaluative issues of our days; in other words, it may help us understand how best to build our civic community and conduct our lives.

What follows here are, first, some reflections about the relation between ancient history and contemporary political theory and, second, an attempt at extrapolating some theoretical understandings of liberty from the historical specificities of the contexts analysed in the following contributions.

The understanding of the relation between the study of history and contemporary political theory highlighted above, not very new per se, is far from uncontroversial. The relationship between history and political philosophy has of course been fiercely debated by political philosophers as well as historians. ${ }^{9}$ For some of the former, history is needed to address the two important issues of universalism

\footnotetext{
${ }^{8}$ For a not dissimilar project, coming to fruition approximately at the same time as this work, and focused on the relevance of ancient Greek political thought to contemporary concerns, see the special issue of Polis, Approaches and Methods in Greek Political Thought, Vol.33.1 (2016) edited by R. K. Balot.

${ }^{9}$ On the latter see, for example, G. Graham, 'Macintyre's fusion of history and philosophy', in J. Horton and S. Mendus (eds.), After Macintyre (Cambridge UK, 1994), 161-75; M. Philp, 'Political theory and history', in D. Leopold and M. Stears (eds), Political Theory: Methods and Approaches (Oxford, 2008); and R. Tuck, 'History', in R. E. Goodin and P. Pettit (eds.), A Companion to Contemporary Political Philosophy, 2 vols. (Oxford, 1993), I, 69-87. On the former, see, for example, Jonathan Floyd and Marc Stears, (eds), Political Philosophy versus History? Contextualism and Real Politics in Contemporary Political Thought, (Cambridge UK, 2011) as well as Terence Ball, Reappraising Political Theory: Revisionist Studies in the History of Political Thought (Oxford, 1995), 1-61; T. Ball, "Must Political Theory Be Historical?", Contributions to the History of Concepts, 2.1 (2006): 7-18; and Conal Condren, The Study and Appraisal of Classic Texts. An Essay on Political Theory, Its Inheritance, and the History of Ideas (Princeton, 1985). See also J. Floyd, 'Is political philosophy too ahistorical?', Critical Review of International Social and Political Philosophy, 12: 4 (2009): 513-33.
} 
and realism. According to one recent statement of this point of view, history can assist in the attempt to strike a balance between 'understanding political principles as timeless prescriptions, applicable and determinate in all times and all places, and understanding them instead as theoretical distillations of whatever moral culture it is that we happen to find ourselves a part of'. It can also help mediate the utopian and the achievable, since by drawing on 'the history of political practice, political philosophers are required to work out just how ambitious political philosophy ought to be in its prescriptions.' ${ }^{10}$

Unlike many of their modern and early-modern colleagues, however, ancient historians have not reflected at length upon the relationship of their subject to political philosophy, and the topic is indeed conspicuously absent in the most recent works on the methodology of ancient history. ${ }^{11}$ Although the reasons for this are not immediately evident, what I believe lies behind a scholarly trend, at times apparently disinclined towards methodological self-reflection, is to be found in the historical development of the discipline as a whole.

Although recent work has shown the innovative nature of studies of the ancient world in the eighteenth century, highlighting the novelty of the Enlightenment contribution to the study of ancient history, it remains true that the most significant formative developments in the discipline were initiated in scholarship in Germany in the second half of the nineteenth century. ${ }^{12}$

Here, within the institutional context of the universities (in contrast, for example, to the world of amateur scholarship in eighteenth-century Britain) which also provided a framework for robust and sustained scholarly self-advertisement, a new research methodology was developed that would be of paramount importance: Quellenforschung, a specific technique of philological scholarship that had risen to prominence in Germany, and spread to other parts of Europe in the late nineteenth and early twentieth centuries. ${ }^{13}$ As a form of source criticism, Quellenforschung deconstructs transmitted ancient texts and establishes a relation of dependence between them by focusing on inconsistencies and errors, and by seeking out non-preserved sources through painstaking comparative work aims to reconstruct lost texts.

The dominance of this distinctive philological methodology in ancient history has had significant effects on the discipline in its modern form. Questioning how texts have come into being led to an emphasis on questions of origins rather than of identity, which in turn generated a preoccupation with the issue of the historical reliability of the information provided by these texts. Philological source criticism of this kind thereby played an essential role not only in the (somehow, at times, arbitrary) construction of the past, but also in establishing a particular relation between past and present, now

\footnotetext{
${ }^{10}$ Floyd and Stears (eds), Political Philosophy versus History?, 2-3.

${ }^{11}$ See, for example, Neville Morley, Theories, Models, and Concepts in Ancient History (London - New York 2004) and K-J Hölkeskamp, Reconstructing the Roman Republic: An Ancient Political Culture and Modern Research, translated by Henry Heitmann-Gordon; revised, updated, and augmented by the author (Princeton Oxford, 2010).

${ }^{12}$ For the revival of studies in classical history in the eighteenth century as the foundation of modern historiography of the ancient world see J. Moore, I. Macgregor Morris and A. J. Bayliss (eds.), Reinventing History: The Enlightenment Origins of Ancient History (London, 2008) with also the review by Kostas Vlassopoulos in Reviews in History 2009.

${ }^{13}$ On this see G. Most, 'The Rise and Fall of Quellenforschung', in A. Blair and A-S. Goeing (eds), For the Sake of Learning: Essays in honor of Anthony Grafton, 2 vols (Leiden - Boston 2016), II, 933-54.
} 
characterised by a profound hiatus. Ancient texts were no longer taken at face value. Nor, when they were seen to be too imaginative to be historically reliable, was their validity assessed according to general criteria of plausibility or to the reader's own values. ${ }^{14}$ Instead, the process of reconstruction set in motion a process of objectification, which subtly, at times unconsciously, and always pervasively, fostered an experience of estrangement. Once the past had been objectified in this way, the categories of time or of historicity, as Hartog calls them, came to give order and meaning. ${ }^{15}$

This new method of 'scientific' scholarship moved beyond the traditional grand narratives, which in previous generations had been firmly rooted in the idea of historia magistra vitae and on the assumption of a shared set of values across time, providing thereby also arguments for contemporary political debates. In tandem with the development of prosopography, it came to represent the transition from Romantic to Positivist history. The reaction to Hegel's philosophical history of the liberty of the human spirit, which incidentally also produced the school of C. O. Müller and August Böckh, gave rise to the work of later positivist historians, whose vision of the ancient world contributed to the forging of a sense of separation and distance between past and present. ${ }^{16}$

Now, the painstaking labour of reconstructing texts, combined with faith in those very texts, created objects for historians to examine, opening windows on to past reality to inspect. This was predicated upon and reinforced two essential and connected assumptions: that the object of interest and study was firmly rooted in the past, and therefore that none of its aspects, not even its perception, could be altered. As Fasolt puts it, 'even if there were nothing else to unite historians (and chances are that there is not), historians would still at least remain united in this one respect: they study things immutable and gone. ${ }^{17}$

This distinction between past and present, however, and the understanding of the past as both absent and immutable, also inform the experience of the present; and this experience, by contrast, is here and now, and is consistently changing and opening up new pathways to the future. In other words, this type of historical study of the ancient past has not only discredited the idea of the past as an exemplarity to follow or a repository of errors to avoid. ${ }^{18}$ It has also released the idea of a present that contains within it creative potential for the future.

The idea that the present ought to distance itself from the past belongs to an intellectual tradition that is deeply ingrained in Western thought, and has often been reinvigorated by public policies concerning education. ${ }^{19}$ 'The project of modernisation', as Anne Orford describes it, 'is one of invention, in which human beings have the capacity and indeed the responsibility to create societies, laws and institutions that are efficient, just and rational. Unlike our medieval ancestors, we do not harbour the illusion that

\footnotetext{
${ }^{14}$ W. Nippel, Ancient and Modern Democracy: Two Concepts of Liberty? (Cambridge UK, 2016), xx.

${ }^{15}$ F. Hartog, Regimes of Historicity: Presentism and Experiences of Time, Trans. Saskia Brown (New York, 2015), xvi.

${ }^{16}$ O. Murray, 'Ancient History in the Eighteenth century', in A. Lianeri (ed.), The Western Time of Ancient History (Cambridge UK, 2011), 301-6.

${ }^{17}$ C. Fasolt, The Limits of History (Chicago, 2004), 5.

${ }^{18}$ The notion of the errors of the past is the subject of the work edited by B. Dufallo (ed.), Roman Error: Classical Reception and the Problem of the Rome's Flaws (Oxford - New York, 2017).

${ }^{19}$ L. Canfora, Noi e gli antichi. Perchè lo studio dei Greci e dei Romani giova all'intelligenza dei moderni (Milano, 2002).
} 
destiny constrains our freedom to invent and create new worlds. The past is gone and it cannot change. ${ }^{20}$ In an endless stream of modernist manifestos, the creative and imaginative force of the present needs to be freed from the constraints of the past. In a word, it requires amnesia. Those who live in the contemporary world "could not imagine life if their present were cluttered by the laws of ancient Rome, the science of Aristotle, and the morals of Saint Augustine.'21

Yet, according to Hartog, after the fall of the Berlin Wall and the end of the Marxism, we have relinquished any form of progressive, future-oriented modernity and live now in a form of presentism, 'the sense that only the present exists, a present characterized at once by the tyranny of the instant and by the treadmill of the unending now. ${ }^{22}$ In Hartog's 'regimes of historicity', until the nineteenth century we lived under the dominion of the past; in the post-Darwinian age, we were dominated by a regime of the future; and after the collapse of the Soviet Union, the way of representing, conceptualising and representing time has become exclusively determined by the present, which 'recreates the past (and the future) only to substantiate the immediate. ${ }^{23}$ The role of the historian, who, Hartog argues, has to be able to see from a distance, concerns the discovery of something other than the present.

This form of presentism, with its distorting potential to approach the past from the perspective of the present, functions as one of the measures against which historians are usually defined as professional practitioners. ${ }^{24}$ Anachronism, correspondingly, being closely related to it, can only be considered, in the words of Lucien Febvre, 'the worst of all sins, the sin that cannot be forgiven.' ${ }^{25}$ As Fasolt vividly puts it, 'that principle [which historians should follow] consists of one command: thou shalt place everything in the context of its time. This keeps historians from committing anachronism. It places the past under a great taboo in order to prevent a kind of chronological pollution. No one who violates that great taboo may claim to be a true historian. The past is sacred; the present is profane. Anachronism profanes the past by mixing past and present. That is the worst offence that historians qua historians can commit. All other sins can be forgiven, but not this one. Anachronism is the sin against the holy spirit of history.' ${ }^{26}$ What lies at the foundation of this unforgivable 'sin' is the conflation of the present, in which the analysing subject operates, with the past in which the analysed object is set. This collapse of differentiation, as Margreta de Grazia notes, infringes both the principles of epistemology as well as of ethics. ${ }^{27}$ It disallows the knowledge of the other period, and also thereby does not respect its

\footnotetext{
${ }^{20}$ A. Orford, 'The past as law or history? The relevance of imperialism for modern international law', in E. Jouannet and H. Ruiz-Fabri (eds), Tiers Monde: Bilan et Perspectives (forthcoming, Paris: Société de Législation Comparée), quoted from IILJ Working Paper 2012/2 (History and Theory of International Law Series): 1-17, 5.

${ }^{21}$ Fasolt, The Limits of History, 7.

${ }^{22}$ Hartog, Regimes of Historicity, xv.

${ }^{23}$ Hartog, Regimes of Historicity, 17. See also the important considerations in Murray, 'Ancient history in the eighteenth century'.

${ }^{24}$ A. Walsham, 'Introduction: Past and ... Presentism', Past \& Present, 234.1 (2017): 213-217.

${ }^{25}$ L. Febvre, The Problem of Unbelief in the Sixteenth Century: The Religion of Rabelais, trans. Beatrice Gottlieb (Cambridge MA, 1982), 5.

${ }^{26}$ Fasolt, The Limits of History, 6. For signs of the anxiety in the study of ancient history, see Morley, Theories, Models and Concepts, 27.

${ }^{27}$ M. de Grazia, 'Anachronism' in J. Simpson and B. Cummings (eds) Cultural Reformations: Medieval and Renaissance in Literary History (Oxford, 2010), 13-32. For an historical understanding of anachronism and its
} 
constitutive differences, reducing the other to the same as the observer, the time of the past to that of the present. Some historians of the ancient world accordingly take a firm stance against a damaging osmosis between past and present, urging a return to the original mission of the historian: to reconstruct knowledge of the past by means of a comprehensive gathering and thorough examination of the available evidence, which is given sacred pride of place.

Of course, no ancient historian has ever claimed that serious historical investigation can dispense with a close inspection of the sources. However, what characterises this position is an open disdain for what they perceive as superimposed abstract formulations: this methodological stance affirms that the historical method to be pursued is, in the words of one of the most eminent contemporary historians of the ancient world, 'necessarily empirical, and theories [are] only as good as the evidence on which they are based. ${ }^{28}$ On this view, what the historian should focus on is 'the collection, analysis and organisation of a body of evidence that is never explained a priori by a conceptual framework of interpretation. ${ }^{29}$ Such a gathering of information, in essence, should constitute the historian's primary task. Articulating this position upon the firm assumption of a clear distinction between the science of human conduct and historical research, Wiseman argues that it is important 'to understand that what the social sciences need from history (including ancient history) is accurate information, usable data, from which they can construct their own abstract categories of argument; there is no point starting from the abstractions before trying to establish what the evidence can actually tell us. ${ }^{30}$ This position, which is shared by many historians of the ancient world, is ultimately based on, and in turn reinforces, a distinction between the past/object of study (the collectable data that historical research should furnish), and the present/subject who conducts the enquiry, who might pose questions and adopt interpretative frameworks of his or her own time.

There are, of course, some important and interesting exceptions to this trend in the study of the ancient world. Robin Osborne, for instance, has recently stated that, by virtue of the continuity between the classical past and the present time, "presentism is not only inevitable, it is highly desirable. ${ }^{31}$ In

virtues in facilitating a dialogue between past and present see J. Pollmann, Memory in Early Modern Europe, 1500-1800 (Oxford, 2017), esp. Chapter 2, Past and Present: The Virtues of Anachronism. See also Peter Burke, 'The Sense of Anachronism from Petrarch to Poussin', in Ch. Humphrey and W. M. Ormrod (eds) Time in the Medieval World (Rochester NY, 2001), 157-73. For a corrective to the widespread notion that anachronism is a modern concept is the Oxford based project 'Anachronism and Antiquity' directed by Tim Rood and John Marincola, currently under way (2016-19).

${ }^{28}$ T.P. Wiseman, 'Politics and the people: what counts as evidence?' BICS 60.1 (2017), 16-33, 16.

${ }^{29}$ An approach termed 'method à la Millar' by Stéphane Benoist, in Id. (ed) Rome, A City and Its Empire in Perspective / Rome, une cité impériale en jeu (Leiden 2012) 11-12: 'La méthode Millar est particulièrement bien éclairée en ce cas: la collecte, l'analyse et la mise en relation d'une évidence qui n'est jamais éclairée a priori par une grille de lecture conceptuelle.' Cf. 3: 'Sa méthode consiste principalement en l'interrogation sans cesse renouvelée des sources à la disposition de l'historien du monde méditerranéen antique, qu'il s'agisse des sources littéraires, épigraphiques, papyrologiques, juridiques ou archéologiques.'

${ }^{30}$ T.P. Wiseman, review of Joy Connolly, The Life of Roman Republicanism (Princeton, 2015) in American Journal of Philology 136.2 (2015), 372-5.

${ }^{31}$ Most recently, see the special issue of Polis 2016 edited by R. K. Balot that is entirely dedicated to the relevance of ancient Greek political thought to nowadays political life: 'in a spirit that is more or less critical of modernity's self-understandings, the contributors to this special issue show that ancient Greek thought can teach us much that we have forgotten or misunderstood, and thereby improve our grip on what matters the most ... 
fact, he argues, it emboldens 'the willingness to ask questions of antiquity which were not antiquity's questions', which, in turn, allow for the opening of new windows into the world of the ancients.

From a wider perspective, Michael Silk, Ingo Gildenhard and Rosemary Barrow have recently claimed that all Western European culture, having being developed in dialogue with the classical world, is somehow shaped by it. 'On a holistic view', they claim, 'all Western art, literature, thought, indeed 'belongs to' the [classical] tradition insofar as none of it would be as it is without the classical, at some stage, behind it. ${ }^{32}$ In their view, a key constituent aspect of the classical, as they put it, is to endow certain authors and objects with normative values, to the extent that 'scholarly reading practice is problematic if and insofar as they promote a mind-set for which value is irrelevant.' ${ }^{33}$ Cultural artefacts, to be understood as texts as well as works of art, are therefore not regarded as objects of research that serve to challenge accepted certainties, but are rather characterised by an intrinsic element of permanence, if not timelessness, to be regarded as 'repositories of beauty or enlightenment, enhancement of experience or source of inspiration. ${ }^{34}$ From this perspective we should turn to the classical world either because the ancients articulated perennially significant ideas about society and our place in it ${ }^{35}$ or because they constitute a constant fount of beauty, to be appreciated for its aesthetic value. ${ }^{36}$ Advocating an aesthetic turn in classical scholarship, Charles Martindale mounts a case against " "vulgar historicists", scholars for whom the only legitimate interpretation of a Latin poem is one related to its original historical context, a meaning which they believe, in their positivistic fashion, can be recovered from "the evidence." ${ }^{37}$ Although we can imagine an interpretative framework within which the historical and the aesthetic are not mutually exclusive - and it seems that even in its most radical formulations, what is being called for is a recognition of literary value alongside history, biography or politics, rather than an absolute supremacy of the aesthetic - in terms of 'regimes of historicity', it is not hard to see that one of the implications of this 'aesthetic turn' is a re-legitimisation of presentism. The aesthetic reading and experience of ancient artefacts, whatever their nature, are anchored in the present, as 'works of art transcend their context in the sense that they continue to arouse a response in the receiver,' here and now, in what it is experienced in the present, even if they do not call for an application or revival in our contemporary political thinking. ${ }^{38}$

\footnotetext{
even if our engagement with Greek thought does not yield practical solutions, it can help us pinpoint difficulties and suggest viable intellectual alternatives.' (2).

${ }^{32}$ Michael Silk, Ingo Gildenhard and Rosemary Barrow, The Classical Tradition: Art, Literature, Thought

(Chichester, 2014), 242.

${ }^{33}$ Silk, Gildenhard and Barrow, The Classical Tradition, 217.

${ }^{34}$ Ibid.

${ }^{35}$ See, for example, J. Howland, 'Poetry, Philosophy, and Esotericism: a Straussian Legacy', Polis 33.2 (2016): 130-149, which analyses Plato's work within a Straussian interpretative framework.

${ }^{36}$ C. Martindale, 'Performance, Reception, Aesthetics: or Why Reception Studies need Kant' in E. Hall and S. Harrop (eds.), Theorising Performance: Greek Drama, Cultural History and Critical Practice (London, 2010), 71-84.

${ }^{37}$ C. Martindale, 'The Aesthetic Turn: Latin Poetry and the Judgement of Taste', Arion 9 (2001): 63-89.

${ }^{38}$ Martindale, Aesthetic Turn, 82. Contra M. Leonard and Y. Prins (eds.), Classical Reception and the Political, Cultural Critique 74 (Minneapolis MN, 2010), which surveys 'a series of ways in which classical pasts inform contemporary thinking about the political and in turn how modern constructs of the political have conditioned our reception of the past ... what the past makes possible for the future... how it may open the way to an
} 
One thinker who advocated a return to the political and philosophical traditions of antiquity was Hannah Arendt, whose project is currently supported by scholars, who, currently reviving interest in her work, claim that 'thinking with Arendt can help us re-evaluate antiquity in its relationship to modernity', as her encounter with the ancients 'holds the key to understanding some of the most urgent ethical, political, and aesthetic questions of our times. ${ }^{39}$ According to Arendt, the reason and justification for this return to the political thought of antiquity are to be found neither in the exercise of pure erudition, nor in the idea of continuity between ancient and modern traditions, but rather in the extraordinary clarity and acumen with which the ancients articulated the fundamental problems of politics. ${ }^{40}$ Whilst their works are not repositories of eternal values, on this view the ancients should be understood within their own historical reality but without effacing their political value. They should act in the present to highlight, ultimately, its strangeness. Arendt never advocates a return to the actualities of ancient life, but rather a conceptual interaction with the ancients in political terms.

Building on a similar premise of discontinuity between ancient and modern traditions, Joy Connolly has recently advocated a return to the ancients (especially the Romans) to address issues of contemporary political concerns. In her The Life of Roman Republicanism, she aims to recover the 'suppressed history of republican thought" ${ }^{41}$ and demonstrate how it can help us to 'think through the challenges of citizenship in a liberal democracy, and especially the tragically pressing predicaments of poverty, exclusion, and apathy. ${ }^{42}$ By reorganising the Republican canon in such a way as to give new emphasis upon texts often marginalised in the discussions of Republican tradition, such as Cicero's Verrines, Caesarean orations, and Horace's Satires, and 'articulating learnable practices of knowing the world $^{43}$ in those texts, Connolly aims to offer practical tools for contemporary civic education. What seems to authorise this investigation is not a sense of continuity - 'we are not', she states, 'the direct descendants of the Greek and the Romans' (1) - but rather some specific and distinctive similarities between, on the one hand, the historical context of Cicero and Horace, and, on the other, the world we live in today. In her reading, authors such as Cicero, Sallust, and Horace grappled with issues very similar to ours: not only failure, she argues, but also self-knowledge and its limits, the horrors of moral certitude, violence, class conflict, corruption, and the decay of the moral discourse. 'Though the Hellenophilic nineteenth century purged these texts from philosophy and theory, their topics are relevant and crucially important for the twenty-first century. For these reasons, they deserve recovery. ${ }^{, 44}$ To scholars who oppose Connolly's intellectual operation of recovery, objecting not on methodological grounds to her application of ancient texts to contemporary concerns per se, but rather because it is an imperialist, hierarchical, and slave-based society whose values Connolly appears to want to revive, she

alternative future, a future that has been concealed or obscured by the present, and to which the past, paradoxically, allows us access.' and Hall and Harrop (eds.), Theorising Performance.

${ }^{39}$ M. Leonard (ed.), Hannah Arendt and the Ancients, special issue of Classical Philology 2018. On similar conceptual premises see the editorial series of Tauris Ancients and Moderns.

${ }^{40}$ H. Arendt, Between Past and Future: Eight Exercises in Political Thought (London, 2006), 143.

${ }^{41}$ J. Connolly, The Life of Roman Republicanism (Princeton, 2015), 206.

${ }^{42}$ Connolly, Roman Republicanism, 15.

${ }^{43}$ Connolly, Roman Republicanism, 208 (author's emphasis).

${ }^{44}$ Connolly, Roman Republicanism, xvi. 
replies that it is precisely for these unpleasant reasons that 'Rome is relevant to contemporary experience. The array of resemblances between the ideological and material conditions of Roman and modern politics is striking and suggestive ... But my reason for rereading Roman thought,' she continues, 'reaches beyond these resemblances. It is because elitism, racism, sexism, slavery, and nativism have been and to a degree remain institutionalised in the exclusionary and discriminatory laws and practices of modern democracy that the Romans are still useful for us.' Ultimately, their true function is to hold up 'a mirror to our political weak spots and our deepest sources of silent social disquiet $^{45}$ so that we may reshape the ways we think about our political world.

\section{III}

This special issue is grounded in the belief that the obstacles placed by the dichotomy between historical research and our orientation in the present are not insurmountable, and indeed that a dialogue with the present is almost an imperative for scholars of the ancient world who wish to engage with the world we live in seriously and substantially.

Based on the assumption that there is not a linear progression throughout history, but rather that the relation between the ancient past, its reception throughout the centuries, and our own time is causally interdependent, ${ }^{46}$ this study not only investigates the notions of ancient liberty in the forms that they were diversely conceptualised in a range of ancient societies, including the Late-Bronze-Age polities in the Levant, the Hellenistic city-states of the third and second century BCE, and late-antique Byzantium, but also attempts to identify whether these ideals can help us think about general issues that we ourselves face in our contemporary society. ${ }^{47}$

The central conceptual focus is upon notions of political liberty, as they related to more specific ideas about the liberty of the state and the liberty of the individuals manifested within the specific contexts being investigated in each case. These aspects of liberty are, of course, closely related to one another: the liberty of the individual or of a group, which in several of these societies was expressed in religious terms, was often conceived as best guaranteed within certain institutional arrangements assumed by the commonwealth.

In what follows, the aim is to provide something in the nature of a chart, in an attempt to situate a number of important ways of conceptualising ancient liberty in their appropriate historical place. Here, addressing some of the issues raised by Kinch Hoekstra and Quentin Skinner in their comments, I attempt to highlight the analytical conceptualisation of these notions of liberty, embedded in the very detailed historical examination of the essays. Although the main purpose of this collection is primarily

\footnotetext{
${ }^{45}$ Connolly, Roman Republicanism, 16 and 17.

${ }^{46} \mathrm{Cf}$. Nippel's reconstruction of the attitude of the XVIII and early XIX century towards the ancients: 'It was, according to Otto von Gierke, 'less a matter of what the Greeks and Romans thought about state and law, than what survived in the reception process, and what they were thought to have believed.' (Nippel, Ancient and Modern Democracy) and Leonard and Prins, Classical Reception and the Political.

${ }^{47}$ For this approach, see Q. Skinner, 'The idea of negative liberty', in Vision of Politics (Cambridge UK, 2002) II, 190-5 and Skinner, Liberty before Liberalism, 109-20.
} 
historical in nature, that is, it aims to investigate the ancient historical contexts within which principles of liberty have been elaborated and adopted and to identify, wherever possible, their context of rational justification, these essays collectively aim also to explore the presence of general theories of liberty, potentially applicable beyond the ancient world.

Adopting what Cécile Laborde has termed an 'analytical' or 'abstracting' approach to the territory, in what follows I attempt to go beyond the historical specificities of individual contexts and, filtering out what is historically particular, try to translate the notions into general categories, providing them with a logical structure. ${ }^{48}$ Rather than providing a genealogy of ancient notions of liberty, as this would require, amongst other things, the identification of a distinctive and somehow unified (albeit articulated) intellectual tradition, ${ }^{49}$ I sketch a taxonomy (inevitably incomplete) of the conceptual tools adopted in these ancient societies. In the broadest terms, two main 'traditions' of political thought can be seen to emerge, each providing the means to conceptualise the notion of liberty in ancient societies: the Jewish tradition of the Hebrew Bible and its antecedents, discussed by Eva von Dassow, Jonathan Stökl, and Philip Wood, and the intellectual tradition of Plato and Aristotle that was reshaped, moulded, and deployed down to the late Roman empire, and even, as Anthony Kaldellis shows, in Byzantium.

In von Dassow's reconstruction of the notion of liberty in the Late-Bronze-Age Levant, liberty is equated to the status of non-slavery. This status entailed the duty to serve the state in the person of the king, or, in case of exceptions that could be granted by the king, the gods. To be in a state of servitude, therefore, as von Dassow shows, meant that an individual was unable to perform their duties to the state - unable, that is, to contribute a share of his labour, wealth or even life to the maintenance of a polity that they considered to be their own, and of a government that they regarded as legitimate. Accordingly, in the texts examined by Eva von Dassow, this status of inability may be caused by the state in two ways: first, when the government is alienated from the people and makes demands that are perceived as oppressive or abusive; and second, as a result of debt bondage. In the latter case, the state fails to protect the rights to property of its citizens. Although this may appear counterintuitive, the possession of property or, more generally, a condition of economic independence, was not considered to be one of the definitional rights that constituted liberty. Liberty consisted instead in the ability to serve the state, which in turn was secured by the holding of property rights, and entailed also the holding of civic rights. Contrary to a classical Greek notion of liberty, explored by Ben Gray, this ideal of servitude to the state, however, was not understood as the citizens' opportunity fully to realise their potential within the civic arena.

In the analysis of von Dassow, in these societies of the late Bronze Age in the Levant, to be free is prima facie paradoxical: in these societies, citizens are free when they are able to contribute to the preservation of a government, which is ruled by a king. However, predicated on the assumption that the

\footnotetext{
${ }^{48}$ C. Laborde, Critical Republicanism. The Hijab Controversy and Political Philosophy (Oxford, 2008), 5.

${ }^{49}$ On genealogy see R. Geuss, 'Nietzsche and genealogy', European Journal of Philosophy 2.3 (1994): 274-292 and the dialogue in Journal of History of Ideas 73.1 (2012). between M. Lane ('Doing Our Own Thinking for Ourselves: On Quentin Skinner's Genealogical Turn') and Q. Skinner ('On the Liberty of the Ancients and the Moderns: A Reply to my Critics').
} 
state is conceived of as the gathering of all members of the community that govern itself through monarchic governance, not only is constitutional form of the state crucial to the upholding of the ideal of liberty amongst the members of these polities; of paramount importance is also the way in which the central power operates: if the state behaves abusively, or is perceived to do so by its members, this fosters a sense of alienation that may provoke a coup d'état or open rebellion.

The potential tension inherent in this account, in which liberty is understood as the ability to serve the state - and by extension the gods - is dramatised in the mid-second-millennium 'Song of Liberation.' The essential condition for the implementation of this ideal of liberty was the redemption of debts of a community (as well as of an individual or family). However justified, this could not have lasted longer than the period commensurate with the sum of the debt, otherwise the deities to whom originally the subjects belong would have imposed penalties on those in power. The crux of the matter was that the permanent subjection of free men was considered unjust, because members of the community were ultimately expected to worship the deity, the true giver of liberty.

In this context, redemption from servitude for debt thereby leads to a condition of true liberty, which consists in the ability to serve the deity. However, when debt, understood in moral terms, comes to be analogically conceived of as a sin from which an individual should be absolved, the ultimate authority able to do so is the deity, from whom both life and liberty derive. This move prompts a clear shift in the understanding of liberty in these communities: a conceptualisation of liberty as the ability to serve one's own state, in the person of the king, and to contribute to the running of the community - and thereby not to live in a status of complete subjection to those who exercise power - became the ideal to serve the deity, because only in a state of absolute submission to the deity, the only giver of liberty, can one fully realise one's own self. This conception of liberty, as Jonathan Stökl shows, was fully embraced by the Church Fathers in the first millennium CE, who attached a performative act of moral responsibility to the idea of debt and turned it into something morally unacceptable. The Church Fathers, in Stökl's account, reinterpreted Leviticus 25:10 in the spiritual terms of the forgiveness of sins, and the release from debt thereby came to be understood as liberation of the soul. In this reading, which was subsequently taken up by the non-Chalcedonian groups discussed by Philip Wood, liberty was the adherence to God's will; it coincided, that is, with the realisation of one's own potential against the constraints of the inner self.

It is important to note, however, that this theological understanding of liberty does not imply a rejection of politics. Rather, it is fundamentally predicated on a crucial relation to the state. It is the abolition of terrestrial debts, in fact, that guarantees men the ability to serve God, and thereby not only to realise their own intrinsic essence, but also to serve other human beings. It is only by being free, as von Dassow argues, that men were allowed (and able) to serve the state, personified in the first place by the king, but also, as she argues, by the wider civic community. As Kinch Hoekstra points out in his illuminating comments on the paper of Eva von Dassow, this was an ideal of liberty understood as an ability to serve the state, that is, a liberty that entailed duties, as well as rights, which had to be protected by the state, whose administration of power should never alienate the citizens. Those rights entailed the 
direct interference of the government in protecting private property and cancelling debts. Interestingly, though, the cited texts do not seem to advance an argument in favour of economic equality within the intellectual framework of liberty. To serve the state, the duty which in these texts provides the domain within which liberty may come into being, it appears sufficient not to be in a condition of slavery. ${ }^{50}$

Similarly, in the Hebrew Bible, as Jonathan Stökl shows, the ideal of liberty was predicated on the periodic ratification of cancellation of debts. In the passages discussed by Stökl, liberty is conceptualised as a status of ability to be as God wishes, and being in a status of debt bondage or indentured labour is said to be contrary to divine will. There is a significant contrast here with the texts from Ugarit and Emar from the second millennium BCE, where the gods do not wish the people to endure servitude for longer than necessary, as they are their ultimate owners and therefore the ultimate receivers of their worship. However, in the Hebrew Bible the God of Israel, YHWH, who is the true owner of the land, watches over the potentially exploitative behaviour of the wealthy Israelites against the more disadvantaged members of the community, by guaranteeing that every Jubilee each Israelite family is endowed with at least the same minimum amount of land. The enactment of this ideal of liberty, which coincided with adherence to God's will, is unconstrained by a condition of economic disadvantage and the ensuing slavery; it is aimed at the restitution of a previously held status quo, characterised by the absence of debt, and at strengthening the patrimonial household, conceived of as the ideal organisation unit of the community. Unbound by external constraints, this condition of liberty, Jonathan Stökl argues, came to be interpreted in Rabbinic exegesis, as liberty to perform business transactions always in obedience to divine law.

Turning to the fifth and sixth centuries in the Eastern Roman Empire and Sasanian Iran, Philip Wood addresses the aftermath of the council of Chalcedon in $451 \mathrm{CE}$, and considers the way in which the relationships between the two opposing groups resulting from the schism led to the non-Chalcedonian religious communities reconceptualising liberty as acting according to the will of God - or, to put it more precisely, to what they understood God required of them. For these groups, it was only in the enactment of God's wishes, which encompassed the establishing and reinforcing of community boundaries, and also the persecution of those who oppose their God, that their members could achieve a status of liberty. In their discourse, which, as Wood shows, constituted a distinctive form of political thought rooted in the biblical model of the chosen people in exile (in striking contrast to the tradition of Plato, Aristotle and Cicero), this liberty could be realised only in absence of constraints, exercised by inner passions as well as by heretical government, which were considered hindrances to the enactment of God's will. One clear consequence of this position is the advocacy of withdrawal from corrupt and corrupting society, and the endorsement of a strenuous opposition to the state. In such a view, the key means of securing the status of liberty is the exercise of parrhēsia, to be understood not as one of the distinctive rights of Hellenistic city-states illustrated by Ben Gray in his essay, but rather as the courage to speak openly following divine inspiration, which, alongside the exercise of virtue, is held to

\footnotetext{
${ }^{50}$ On this issue A. Sen, Inequality reexamined (New York, 1992) who makes an argument for economic equality based on liberty.
} 
embolden the members of the groups to hold assemblies. Courage and virtue of this kind will then remove the fear of tyranny and enable the opposition to heretics. Such are the means to achieve the status of liberty.

A striking difference in this theological conception of liberty from that elaborated in the Late-BronzeAge Levant or in eighth-century BCE Israel is that the political agents whose liberty was in question were neither the individual members of the community, nor the civic community as a whole, but rather minority groups who defined themselves by their religious identity. Accordingly, and in further contrast to the other two historical contexts of the Near East analysed here by von Dassow and Stökl, where liberty came to coincide with the service to God, there is no reference to individuals' right to property. Rather, their viewpoint was framed, as Wood writes, 'in terms of communal liberties [of the minority religious groups] rather than individual ones. ${ }^{51}$ These non-Chalcedonian religious groups, in fact, conceived of their liberty in terms of the liberty of their communities against both non-Christian cocitizens as well as the Roman state. As Kinch Hoekstra observes, however, this notion of liberty is predicated upon the assumption of a religious truth that aims at being all-encompassing and does not seem to tolerate the other, whoever s/he might be, who does not share the same fervent belief. This conceptualisation of liberty perhaps serves as an admonition against all sorts of current ideological extremisms.

The Roman conception of liberty in relation to religious groups both in the Republic and the Empire is investigated by Clifford Ando. In Rome, he argues, legal texts as well as instruments of law identify religion as a concern of juridically constituted communities, as opposed to a concern of individuals, which was conceptualised by means of linguistic categories of political belonging and Republican citizenship. In this account, which is set within a wide framework of communal culture and commitments to the state, forms of worship that did not act against the commonwealth (or more specifically, the state authority) were tolerated. However, in contrast with the situation in Hellenistic cities contemporary to Republican Rome discussed by Ben Gray, this liberty of religion was not articulated in terms of individual liberty from interference, enabling one to make one's own preferred choice in matters of religion. Rather, Ando argues, it was predicated upon the ideal of the group as reference point, which highlights the distinction between notions of liberty applied to a collective and those applied to an individual. ${ }^{52}$ If, on the one hand, 'the civil mode of toleration', as Ando calls it, permits the coexistence of both the private and the public religious commitments of an individual, without a particular interest in the sphere of private religiosity, the so-called imperial mode of toleration, on the other hand, advocates toleration towards the religion of groups included and subjected to the Roman domain. Hence, although at first sight the Roman empire and the Republican nature of Roman law and thought in respect of religion may seem to be compatible with some form of religious pluralism, on closer inspection this model, as it was articulated and implemented in Rome, is not adequately

\footnotetext{
${ }^{51}$ See Wood below, 000 .

${ }^{52}$ See G.A. Cohen 'The Structure of Proletarian Unfreedom' Philosophy \& Public Affairs 12.1 (1983): 3-33 on the liberty of a group and of an individual and J. T. Levy, Rationalism, Pluralism, and Freedom (Oxford - New York, 2015).
} 
equipped to address contemporary issues raised by minority groups with distinctive religious identities. By laying such heavy emphasis on the ideal of political citizenship to the detriment of cultural and religious identities, which play a large part in contemporary political debates, it is questionable whether a classically modelled Republicanism is able to address the role of religion as definitional component of identity. Indeed, we might further ponder the potentially problematic implications of the consideration of groups, rather than individuals, as the fundamental point of reference in discussions of liberty. As Cécile Laborde has observed, according to contemporary Republicans, although cultural and religious identities hold great importance in the lives of the people, such identities should not have a substantial impact on their political citizenship and 'should be transcended through political engagement in a culturally and religiously neutral public sphere, and/or subsumed by an inclusive national identity. ${ }^{53}$ It is not so much that, by re-elaborating ancient Roman thought, the currently revived Republicanism requires civic religion, nor that it fails to articulate the need for religious liberty in terms of individual rights; but rather, that according to this tradition of thought, the political dimension of the individuals as well as the whole civic community holds primacy, while their religious sphere of existence may be perceived as subsumed by it. By focusing on a notion of citizenship as an exclusively civic model of active virtue, this tradition of thought might be said to be unable to capture the religious pluralism of different groups in our contemporary society. At the very least, this aspect of classical republicanism seems problematically misaligned to the self-evidently dominant contemporary concerns, themselves often expressed in the contrasting political language bestowed by modern liberalism, with cultural and religious identity.

\section{IV}

As Ando's analysis of the Roman empire demonstrates, such concerns are pertinent to our understanding of the territory of the classical intellectual tradition. In her essay, Melissa Lane revisits one of the most well-known documents of this tradition, focusing on Plato's conceptual innovation in the history of liberty in the Republic. Plato, she argues, does not understand virtuous psychological selfmastery as positive freedom. Rather, reflecting on the idea of the badness of the status of slavery, he elaborates a notion of freedom as liberty of action and choice of citizens, which should be compatible with willing obedience to laws as well as to magistrates in office. Within an intellectual tradition where, as Skinner observes in his comments, law is perceived as an agent liberating the citizens from the danger of enslavement, Plato is here shown to elaborate a conception of liberty in which the willing obedience to the rule of laws and magistrates, as well as the virtuous disposition of the citizen's soul, are the two features that most befit a person of free status. One important argument, brought to the fore by Lane in her analysis of the figure of the tyrant, is that for Plato, to be free requires the ability to rely on other persons who should guarantee the space for free actions in a way befitting those who enjoy free status.

\footnotetext{
${ }^{53}$ Laborde, Critical Republicanism, 2. In this work, Laborde suggests ways in which Republicans can address and solve the issue of contemporary demands for the recognition of religious diversities in the public sphere.
} 
In other words, the establishment and preservation of liberty requires solidarity and trust, which are expressed in the language of civic friendship, and good judgment. These, in turn, require a constitution that establishes offices as well as a set of laws, for which the citizens' obedience to laws and magistrates is a necessary condition. 'It is in terms of constitution and of friendship,' Lane tells us, 'and not in the narrow terms of slavery itself, that the willingness to accept rule can be located. ${ }^{54}$ The emphasis on this dual nature of liberty, whose existence is predicated upon the acceptance of a form of enslavement not only to laws but also to those who exercise power, calls attention to the modalities of education required for living in a civic community. It also depends upon civic virtue on the part of the magistrates, who are called to act in virtue of their office as well as of the institutional arrangements that guarantee a system of accountability.

The Classical approach, here generally exemplified by Plato's thought, was re-elaborated, modified, and moulded in the historical contexts of the self-governing Greek city-states between the late fourth century and the first century BCE. Ideals of liberty based on a robust understanding of civic virtue and the common good, which made considerable demands on the citizens of Classical Greece, including, as Lane illustrates in the case of Platonic thought, the willing obedience to the rule of law and to the magistrates in office, were combined with a notion of liberty as absence of interference or coercion to pursue one's own chosen ends. As Ben Gray shows, citizens of the Hellenistic city-states reimagined Greek civic ideals to adapt and foster civic life within a new, cosmopolitan, environment. When talking about the internal functioning of their civic community, Hellenistic citizens tended to emphasise core values of civic virtue and engagement, benefactions to the community, reciprocity and reciprocal justice. They did so, however, by developing alongside these Greek traditional civic ideals an interest in individual freedoms, particularly concerning property and property disputes, as well as providing greater scope for individual reflective choice (prohairesis or hairesis) and diversity within the citizenbody. The development of sustainable ethical choices, understood as preferential dispositions of the citizens, Gray argues, was made possible by participation in the unique types of education and social interactions provided by the polis. As Hellenistic decrees show, the elaboration and strengthening of citizens' dispositions and prohaireseis was favoured by the civic education and habituation of the polis, which in turn meant that a well-functioning polis, incorporating an honorific process for civic virtue, was a well-suited environment for the fashioning of informed choices.

This Hellenistic elaboration of the ideal of liberty was coeval with the development in Rome of a Republican notion of liberty, which found full articulation in Cicero's works.

In his De re publica, in the so-called speech of the democrats, which, according to some scholars, owes much to a Greek source, Cicero puts forward the argument that to achieve liberty, understood in terms of absence of domination or dependence on the arbitrary will of anyone else, it is not sufficient to hold a matrix of individual rights; rather, it requires full participation in politics. This, in turn, could be achieved through the exercise of the right to suffragium in legislative as well as electoral contexts, that is in enacting legislation and electing magistrates, and also, and crucially, through the right of being

${ }^{54}$ Lane, see below, 000. 
elected in turn. Whilst subjection to the laws is central to the ancient Republican ideal of liberty - 'we are all slaves of the law, so that we may be free', Cicero famously states in the pro Cluentio (146) and, as Skinner reminds us in his comments, ${ }^{55}$ political participation in the legislative process was considered also by later Republican or neo-Roman thinkers the best means to achieve liberty, in the democratic argument as reported in Cicero's De re publica the right to be elected is not, in Atkins' reading, successfully predicated on the notion of liberty as non-domination, as, in his analysis, it fails to show "why a state of non-domination cannot be adequately established by the notions of equality of citizens before the law and a largely defensive set of citizens' rights. ${ }^{56}$ It is, nevertheless, successfully put forward by Cicero, Atkins argues, with regard to the members of the elite, who are the repositories of the highest degrees of dignitas. Operating within the same intellectual tradition as Scipio, according to whom a man is free not only when in a status characterised by the absence of domination, but also, importantly, when he himself is able to act on his own will (fr. 32, Malcovati, 134), Cicero claims that the members of the elite should be not only equally protected, but also equally empowered. ${ }^{57}$

Scipio and Cicero here seem at first to differ from Cato, who in a famous fragment states that to establish and maintain the citizens' liberty, it is necessary that all members of the political community share the same rights on the same basis, while gloria, dignitas, and honor - depending on personal circumstances and merit - will allow for individual differentiation amongst the citizen body. ${ }^{58}$ What these two interpretations of liberty have in common is a basic understanding of liberty as a status of non-domination. Where they diverge, however, is on the conception of equality they consider essential to the establishment of free status, and correspondingly the related conditions they regard as sufficient to protect the citizens from the arbitrary imposition of someone else's will upon them. Whilst for Cato the communally shared possession of civic and political rights, which include the right to vote, but not to be voted on, is sufficient to guarantee the citizens' liberty, Scipio adds that, next to the absence of a condition of domination, citizens should also hold the power of dominating. If, as seems most probable, his fragment refers to the role of an individual, rather than that of the populus Romanus as a whole, Scipio's conception of liberty requires not only the absence of something, but also the presence of something else: the enjoyment of power, which for him should be held only by those who could claim the innocentia and dignitas that are conducive to honor, and will lead to power and eventually, liberty. ${ }^{59}$

However, if this is indeed the case, Atkins observes, this conceptualisation of liberty prompts the reflection that, alongside the issues of domination, control, and ownership, we also need to consider questions of status, political participation and empowerment. The understanding of Republican liberty

\footnotetext{
${ }^{55}$ Skinner, below, 000.

${ }^{56}$ Atkins, below, 000. For a different interpretation of this passage and the identification of a democratic tradition of Republican thought, see Arena, Libertas, 142-3 and 000.

${ }^{57}$ For the ways in which Scipio's and Cicero's views differ from those of Cato see Arena, Libertas, 143.

${ }^{58}$ Cato, fr. 252 (Malcovati 1955, 96).

${ }^{59}$ Arena, Libertas, 143. See J. Rawls, 'Equal liberty' in A Theory of Justice (Cambridge MA, 1971), 171-227, which distinguishes between liberty, a set of basic rights enshrined in the constitution, and the worth liberty, which varies according to the individual ownership of resources to achieve one's own end.
} 
expressed by Scipio and Cicero is dangerously congruent, Atkins reminds us, with a hierarchical, slaveholding, paternalistic, and, one may add, imperialistic regime. ${ }^{60}$

The Roman Republican ideal of liberty as the antonym of slavery, that is as a status of absence of arbitrary interference on the part of anyone else, was preserved and further re-elaborated during the later Roman empire and Byzantium.

Perceiving themselves as Romans, Kaldellis argues, the Byzantines held a notion of liberty as the absence of domination, externally from the barbarians and internally from abuses of domestic power. The emperor himself, in this vision, was not perceived as a threat to liberty, but rather as its bulwark. Through the preservation of a lawful polity, which protected Roman citizens from the despotism of arbitrary power, the emperor provided the guarantees for the establishment and the preservation of liberty (against, mainly, an oppressive elite), which, in turn, furnished the political system under his rule with a form of political legitimacy. However, when the emperor himself turned into a domineering despot (or, as they called him, tyrant) who deprived the people of their liberty, the Byzantines rose up against those emperors - or supported those internal rebels who were trying to do so - and fought for the restoration of liberty. In Byzantium, as Kaldellis shows, liberty was far more than a rhetorical trope. It was a cultural and political norm that spurred citizens into action. Contrary to traditional misconceptions, then, the Byzantines were far from being apolitical. For them the protection of rights was an issue of paramount concern, for which they were prepared to fight. This may be a salutary reminder for us, now so often subject to domination by the silent exercise of powers to which we have been alerted by Skinner.

\section{V}

The contributions to this special issue do not attempt to uncover or excavate a new way of thinking about liberty that was solely distinctive of antiquity, but collectively aim to do justice to the complexities and richness of the ancient conceptions of this idea. In particular, they highlight a series of issues of pressing importance for contemporary thinking about the civic community: the significance of religious identity and its preservation in a free society; how the value of liberty may be preserved in conditions of economic inequality; the relationship between the liberty of a group and the liberty of the individual, and the question of the extent to which a group may be endowed with liberties of which its individual members are deprived (or vice versa); the relationship between liberty and notions of autonomy and equality; and the means by which the development of a psychology of civic virtue might be fostered, alongside institutional systems of voting and accountability, to establish and preserve liberty.

This historical investigation shows that the contemporary notions of liberty, contested throughout centuries, are the result of possibilities opened and closed in the past, the results of choices made by past societies. ${ }^{61}$ This is the most salutary reminder, as is often said, of the contingent nature of our

\footnotetext{
${ }^{60}$ Atkins, below, 000.

${ }^{61}$ Lane, 'Doing Our Own Thinking for Ourselves'.
} 
'eternal' values, which, therefore, can, and should, be modified to respond to contemporary challenges. As Foucault contended, the point of history is indeed to show that the present is contingent and can be altered.

The aim of this historical investigation is not to stand in contemplative awe of the achievements of the ancients nor to try to replicate their solutions. Rather, by extrapolating general logical propositions from the specificities of their historical contexts, the purpose of this historical enquiry is to gain new intellectual tools (or refine those at our disposal) that may show us how best to deal with current situations and circumstances.

All together, these essays show a different way to study and write the history of ancient notions of liberty as well as a different way to relate to the past. A viable intellectual resource, these ancient societies, interconnected with one another, are endowed with an imaginative force that may support us in thinking again and with some perspective about what we might need to include or exclude in conceptualising the world around us. ${ }^{62}$

\section{Acknowledgment}

This event has been made possible by the financial support of UCL Grand Challenges Intercultural Interaction and the Institute of Classical Studies, London. Special thanks are due to Fiachra Mac Góráin, Ingo Gildenhard; Martin Goodman, Sophie Lunn-Rockliffe, and Malcolm Schofield, who acted as exceptionally stimulating chairs. In addition, I am grateful to Angus Gowland for comments on a draft of this piece and to Richard Whatmore, for his wise and well spirited guidance during the editing process.

\section{Disclosure Statement}

No potential conflict of interest was reported by the author

\section{Bibliography}

Arena, V. Libertas and the Practice of Politics in the late Roman Republic (Cambridge UK, 2012) Ball, T. Reappraising Political Theory: Revisionist Studies in the History of Political Thought (Oxford, 1995) (2006): 7-18

'Must Political Theory Be Historical?', Contributions to the History of Concepts, 2.1

Balot, R. K. (ed) Approaches and Methods in Greek Political Thought, Polis Vol.33.1 (2016)

Benoist, S. (ed) Rome, A City and Its Empire in Perspective / Rome, une cité impériale en jeu (Leiden 2012)

Burke, P. 'The Sense of Anachronism from Petrarch to Poussin', in Ch. Humphrey and W. M. Ormrod (eds) Time in the Medieval World (Rochester NY, 2001), 157-73

\footnotetext{
${ }^{62}$ J. Dunn, 'The History of Political Theory' in The History of Political Theory and other essays (Cambridge UK, 1996), 11-38.
} 
Canfora, L. Noi e gli antichi. Perchè lo studio dei Greci e dei Romani giova all'intelligenza dei moderni (Milano, 2002)

Cohen, G.A. 'The Structure of Proletarian Unfreedom' Philosophy \& Public Affairs 12.1

(1983): 3-33

Condren, C. The Study and Appraisal of Classic Texts. An Essay on Political Theory, Its Inheritance, and the History of Ideas (Princeton, 1985).

Connolly, J. The Life of Roman Republicanism (Princeton, 2015)

Dufallo, B. (ed.), Roman Error: Classical Reception and the Problem of the Rome's Flaws (Oxford - New York, 2017).

Dunn, J. 'The History of Political Theory' in The History of Political Theory and other essays (Cambridge UK, 1996), 11-38.

Fasolt, C. The Limits of History (Chicago, 2004)

Febvre, L. The Problem of Unbelief in the Sixteenth Century: The Religion of Rabelais, trans.

Beatrice Gottlieb (Cambridge MA, 1982), 5.

Ferrar, M, The Fight for Freedom (London 2016)

Floyd, J. 'Is political philosophy too ahistorical?', Critical Review of International Social and Political Philosophy, 12: 4 (2009): 513-33

Floyd, J. and Stears, M. (eds), Political Philosophy versus History? Contextualism and Real Politics in Contemporary Political Thought?, (Cambridge UK, 2011)

Geuss, R. 'Nietzsche and genealogy', European Journal of Philosophy 2.3 (1994): 274-292

Graham, G. 'Macintyre's fusion of history and philosophy', in J. Horton and S. Mendus (eds.), After Macintyre (Cambridge UK, 1994), 161-75

Gray, B Stasis and Stability. Exile, the Polis, and Political Thought c. 404-146 BC (Oxford, 2015)

Hartog, F. Regimes of Historicity: Presentism and Experiences of Time, Trans. Saskia Brown (New York, 2015)

Hölkeskamp, K-J. Reconstructing the Roman Republic: An Ancient Political Culture and Modern Research, translated by Henry Heitmann-Gordon; revised, updated, and augmented by the author (Princeton - Oxford, 2010).

Howland, J. 'Poetry, Philosophy, and Esotericism: a Straussian Legacy', Polis 33.2 (2016): 130149

Laborde, C. and Maynor, J. (eds.) Republicanism and Political Theory (Malden MA - Oxford, 2008).

Laborde, C. Critical Republicanism. The Hijab Controversy and Political Philosophy (Oxford, 2008),

Lane, M. 'Doing Our Own Thinking for Ourselves: On Quentin Skinner's Genealogical Turn', Journal of History of Ideas 73.1 (2012): 71-82.

Leonard, M. and Prins Y. (eds.), Classical Reception and the Political, Cultural Critique 74 (Minneapolis MN, 2010)

Leonard M. (ed.), Hannah Arendt and the Ancients, Classical Philology 113.1 (2018).

Levy, J. T. Rationalism, Pluralism, and Freedom (Oxford - New York, 2015).

Martindale, C. 'The Aesthetic Turn: Latin Poetry and the Judgement of Taste', Arion 9 (2001): 63-89

'Performance, Reception, Aesthetics: or Why Reception Studies need Kant' in E. Hall and S. Harrop (eds.), Theorising Performance: Greek Drama, Cultural History and Critical Practice (London, 2010), 71-84.

Moore, J., Macgregor Morris, I., and Bayliss, A. J. (eds.), Reinventing History: The Enlightenment Origins of Ancient History (London, 2008) 
Morley, N. Theories, Models, and Concepts in Ancient History (London - New York 2004)

Most, G. 'The Rise and Fall of Quellenforschung', in A. Blair and A-S. Goeing (eds), For the Sake of Learning: Essays in honor of Anthony Grafton, 2 vols (Leiden - Boston 2016), II, 933-54

Murray, O. 'Ancient History in the Eighteenth century', in A. Lianeri (ed.), The Western Time of Ancient History (Cambridge UK, 2011), 301-6.

Nippel, W. Ancient and Modern Democracy: Two Concepts of Liberty? (Cambridge UK, 2016)

Orford, A. 'The past as law or history? The relevance of imperialism for modern international law', in E. Jouannet and H. Ruiz-Fabri (eds), Tiers Monde: Bilan et Perspectives (forthcoming, Paris: Société de Législation Comparée), quoted from IILJ Working Paper 2012/2 (History and Theory of International Law Series): 1-17.

Patterson, O Freedom, Volume 1: Freedom in the Making of Western Culture (London, 1991).

Pettit, P. Republicanism: a Theory of Freedom and Government (Oxford, 1997)

Philp, M. 'Political theory and history', in D. Leopold and M. Stears, Political Theory: Methods and Approaches (Oxford, 2008)

Pitkin, H.F. 'Are Freedom and Liberty Twins?', Political Theory 16.4 (1988): 523-52.

Pollmann, J. Memory in Early Modern Europe, 1500-1800 (Oxford, 2017)

Rawls, J. 'Equal liberty' in A Theory of Justice (Cambridge MA, 1971), 171-227

Rorty, R. Contingency, Irony, and Solidarity (Cambridge UK, 1989).

Schimdtz, D. and Brennan, J. The Brief History of Liberty (Malden MA - Oxford, 2010)

Sen, A. Inequality reexamined (New York, 1992)

Silk, M., Gildenhard, I., and Barrow, R. (eds) The Classical Tradition: Art, Literature, Thought (Chichester, 2014)

Skinner, Q. Liberty before Liberalism (Cambridge UK, 1998) Vision of Politics, 3 vols. (Cambridge UK, 2002-)

'On the Liberty of the Ancients and the Moderns: A Reply to my Critics', Journal of

History of Ideas 73.1 (2012): 127-46.

Strunk, T. History after Liberty: Tacitus on Tyrants, Sycophants, and Republicans (Ann Arbor, 2016).

Tuck, R. 'History', in R. E. Goodin and P. Pettit (eds.), A Companion to Contemporary Political Philosophy, 2 vols. (Oxford, 1993), I, 69-87

Vlassopoulos, K. review of Moore, McGregor and Bayliss (eds), Reinventing History: The Enlightenment Origins of Ancient History (London, 2008), in Reviews in History 2009 (review no. 818), http://www.history.ac.uk/reviews/review/818 [Date accessed: 16 June 2018]

Walsham, A. 'Introduction: Past and ... Presentism', Past \& Present, 234.1 (2017): 213-217.

Wiseman, T.P. review of Joy Connolly, The Life of Roman Republicanism (Princeton, 2015) in American Journal of Philology 136.2 (2015), 372-5.

'Politics and the people: what counts as evidence?', BICS 60.1 (2017), 16-33, 16 